\title{
PLURALIST-MULTICULTURAL ISLAMIC EDUCATION AN ATTEMPT TO REDUCE RADICALISM AND ANARCHY TO A PEACEFUL PLURAL SOCIETY
}

\author{
Burhan Nudin \\ Islamic Education Program, Faculty of Islamic Studies, Islamic \\ University of Indonesia \\ Email:burhanudin@uii.ac.id
}

\section{Abstract}

The paper discusses the role of Islamic education in eradicating radicalism and anarchy. It argues that there are many radicalism and anarchy acts that appear in Indonesia and that military/security approach may not be effective in eradicating radicalism and anarchy in Islam. Another approach is required to solve the problem, namely pluralist-multicultural Islamic education. The main purpose of this approach is on understanding and appreciation among students to their own and others' culture-including religion-and based on Bhinneka Tunggal Ika (Unity in Diversity) as well as Pancasila (the Five Pillars). By applying pluralist-multicultural Islamic education, it is expected that it will be an effective instrument to develop tolerance and peace among students since their early ages; therefore, they will become a pluralist-multicultural generation. In the long run, various radicalism and anarchy acts in Indonesia can be reduced.

Keywords: Islamic education, pluralist-multicultural, radicalism and anarchy

\section{A. Introduction}

Indonesia is one of the biggest multicultural countries in the world. It can be observed from both socio-cultural and geographical 


\section{Burhan Nudin}

conditions of the country. Indonesia is made of thousands of islands, with about 11,000 inhibited islands complimented with 359 tribes and 726 languages. Based on PNPS No. 1 /1969, which is just justified by the Indonesian Constitutional Court, Indonesia recognizes five religions. Under the reign of the fourth president, K.H. Abdurrahman Wahid, Konghucu becomes the sixth religion admitted by the government. Under each religion, there are many factions manifested in form of social organizations. There are also non-religion beliefs that develop in Indonesia.

Good management of the aforementioned groups can be valuable social investment in the nation's development. In contrary, when the management does not run well, plurality built from the existing groups may potentially create conflicts and social disorders. So far, it is proven that Indonesia has not been successfully managed its plurality. ${ }^{1}$

Numerous social problems occurred in Indonesia. These problems led to various loss, for instance, material, social, and mental/ psychological. In parts of Indonesia, there were conflicts that reflect particular society's need to stand out among the others. Horizontal conflicts started from over-fanatic, exclusivism, anarchy, radicalism, and brutalism are the results of plurality which is not maintained appropriately. It will lead to disintegration in the society itself. Each culture basically has its own traditional wisdom. This wisdom cannot be determined as good or bad from the perspective of other culture.

We will look back at several factors that cause radicalism and anarchy in Indonesia. First of all, there are groups that aim at making Islam as the final ideology in regulating individual's life and the country's political constitution. Second, Islamic values embraced by those group are entirely adopted from the Middle East, without considering current local social and political dynamic compared to the era when Quran and Hadith emerged. Third, as more attention is

1 Andik Wahyun Muqoyyidin, "Membangun Kesadaran Inklusif-Multikultural Untuk Deradikalisasi Pendidikan Islam," Jurnal Pendidikan Islam Vol. 2, no. 1 (June 2013): p. 132. 
given to the texts in Quran and Hadith, purification process tends to be restrained in adapting existing local traditions, since it will lead to bid'ah (impurities). Fourth, there are groups that reject Non-Middle Eastern ideology, like Western ideology (including democracy, secularism, and liberalism). Additionally, every single life aspect should refer to Quran and Hadith. Fifth, the groups' movement frequently go against other group or society, including the reigning government. thus, there will be ideological and even, physical frictions with other groups. Sixth, there is historical legacy on Islamic movement that stood against reigning regime. It was due to political oppressions to Islam in the past, especially during the New Order regime. Marginalized groups during the era tried to align the position of Islamic politics through non-state and structural paths. In global context, marginalization of Islamic politics by hegemony in international politics (United States of America) generates a conscience in recurring the power of Islamic politics. Transnationalism brings this conscience to Indonesia in the form of Islamic politics movements. Seventh, there is an economicpolitic phenomenon. Beside political oppression, poverty, and social discrimination, the following argument is the existence of economicpolitic oppression. Here, radicalism appears from capitalism entrance which creates groups without access to capitals. In economicpolitical term, this approach is known as "class approach." It means that radicalism response is basically class response to fight against oligarchic capital hegemony with the state. Therefore, radicalism can be seen as an illustration of historical conscience combined with class conscience. $^{2}$

Radical and anarchic movement will disturb social stability and cause social tension, especially when the movement tends to be militant, strict, firm, and continuingly destructive and chaotic. Besides, radical and anarchic movement tend to uncompromised and intolerant to other groups' need.

2 Muqoyyidin, p. 138. 
Society members who live in harmony change into people who hate, attack, and kill one another. The meaning of living side by side in a plural society blurs into living under certain group's interests. Individual or communal life likely becomes full of suspicion, terror, hatred, unforgiving, and concern, as well as no interest in plurality. This situation is very concerning and raises many questions. What has happened to this nation? Is Indonesia known as a nation which respects differences? How long will this situation last? How to deal with this situation? This paper tries to examine the existing problems in order to achieve clear and objective solutions.

Social conflicts occurred recently cannot be ignored, since they can potentially threat the nation. It can cause disintegration; hence, Indonesia has to start building an image as a civilized, dignified, and respected nation. It can be started from educational side. It is an essential component in preserving and improving the citizen's life quality. Education is the means to develop human potential to reach not only intellectual maturity, but also social and moral maturity. Thus, educational process is developing one's intellectuals, also covering all potential that students have. ${ }^{3}$

In this context, the writer thinks that Islamic education requires more attention, since it is proven useful in creating students who are tolerant, peaceful, and inclusive. Islam is generally translated as 'peace'; thus, Islamic education acts as an instrument to promote peace in plural society which put forward positive perspective on pluralism and diversity.

To make Islamic education a promotional instrument of peace among plural societies in Indonesia, Islamic values and moral teachings have to be internalized and embodied in day-to-day practices. There are some Islamic values to be pointed out. First is justice. It is commonly associated with legal establishment or King's command. However,

3 Wina Sanjaya, Strategi Pembelajaran Berorientasi Standar Proses Pendidikan (Jakarta: Kencana, 2011), p. 135. 
justice in this sense covers various aspects of life. Consequently, 'justice' in Islam covers the relationship among individuals, the relationship between individual and other members of the society, etc. Second is Amar Ma'ruf Nahi Munkar which means a movement to foster righteous actions toward God's blessings. Third is freedom. It basically covers individual, communal, religious, association, and political freedom. Most importantly, religious freedom in Islam highlights the principle of no coercion or obligation in embracing Islam. It means that there should be clear explanations and convincing argumentation throughout the spreading (syiar) of Islamic teachings. Fourth is egalitarianism. It is one of the most important parts in Islamic teachings, especially in stirring and controlling the society. This principle has strong foundation in both Quran and Hadith. The renown Al-Sahifah (Medina constitution) is a real example of Islam's anti-slavery standpoint. Fifth is ta'awun (offering help in kindness). It should mainly refer to tauhid (belief in the same Creator); to kindness and piety. Sixth is tolerance. Islam commands its believers to live in peace and harmony, despite their culture, background, race, tribe, or religion. Hence, tolerance in Islam means to assure guaranteed other believers' rights. It also means that respects among different believers build harmony in society. ${ }^{4}$

Based on the above teachings, Islamic education is expected to create students with good attitudes, ethics, or characters and becomes an alternative in preventing radicalism and anarchy. One of the attempts is implementing pluralist-multicultural Islamic education. The implementation is expected to shape a conscience on the importance of plurality and diversity and becomes an instrument to develop tolerance and harmony among students. In the long run, it will create a generation which advocates humanities.

4 Juhaya S. Praja, Filsafat Hukum Islam (Bandung: Universitas LPPM, Universitas Islam Bandung, 2002), p. 77. 


\section{B. Islamic Education}

In the history of education in Indonesia, Islamic education is generally noted as a specialty in education; a type of education with Islamic background. In Law No. 20/2003 on National Education System, Islamic education is categorized as a type of education conducted in specific patterns and characteristics. There are some divisions on Islamic education, such as, Formal Education Institution (Articles 17, 18, and 20), Non-formal Education Institution (Article 26), Informal Education Institution (Article 27), Early Childhood Education (Article 28), Religious Education (Article 30), and Islamic education as a school subject (Article 37). ${ }^{5}$

There are confusion and ambiguity in understanding Islamic education and its variants. Some people see Islamic education as "Islamic religious education" and vice versa. As an example, subjects related to Islamic teachings in school are referred as "Islamic education"; however, they are more to "Islamic religious education." In Islamic schools, like boarding school and madrasah, the subjects are commonly labelled as "Islamic religious education"; yet, they should be "Islamic education." In this paper, the writer tries to put the classification as followed.

1. Education in Islam or Islamic education is a type of education that is established and developed from fundamental values and teachings of Quran and Sunnah. Here, Islamic education can be in the form of thoughts or educational theories based on the aforementioned sources.

2. Islam-based education or Islamic religious education is a type of education that put emphasis on Islamic teaching and its values to shape one's perspective and attitude. In this sense, the education can be in the form of: a) activities conducted by individual or institution to assist a student or group of students in disseminating and improving Islamic teachings and its

5 Gunawan and Ibnu Hasan, eds., Percikan Pemikiran Pendidikan Islam: Antologi Konfigurasi Pendidikan Masa Depan (Jakarta: Raja Grafindo Persada, 2015), p. 20. 
values; b) events or phenomena when two individuals or more meet one another can give meaningful impact the development of Islamic teaching and its values to the involved parties.

3. Education in Islam is a process and practice of education performed and advanced throughout the history of Islam. In this case, the development process covers Islam as a religion, teaching, cultural system, or civilization from the era of Prophet Muhammad SAW to the current era. Therefore, education in Islam can be comprehended as cultivating and inheriting Islamic teachings, cultures, and civilization of Islam throughout the history. ${ }^{6}$

4. Islamic education is a planned and guided activity to achieve comprehensive Muslim characters. At this point, Islamic education is a conscious guiding process conducted by a teacher to his/her students in order to form individual, family, and society based on Islamic teachings and its values. ${ }^{7}$

Even though Islamic education is comprehended in several different ways, it is essentially united and operationally manifested in an inclusive system. Thus, this education is mainly based on Quran and Hadith which are operationally justified in cultivating and inheriting Islamic teachings, cultures, and civilization of Islam from generation to generation. In practice, this process occurs collectively and inseparably from the process of training and developing Muslim characters in every generation in the history of Islam. ${ }^{8}$

In discussing Islamic education, there are several important points to be discussed, such as, definition, foundation, function, and purpose of Islamic education. First of all, the definition of Islamic education, according to Muhamad Fadhil Al-Jamaly from M. Ridlwan Nasir, is an effort to expand, enhance, and entice society based on respectable

6 Gunawan and Hasan, p. 41.

7 Mahmud, Pemikiran Pendidikan Islam (Bandung: Pustaka Setia, 2011), p. 25.

8 Mahmud, p. 42. 
values and noble life to achieve immaculate character. ${ }^{9}$ Secondly, the foundation of Islamic education is to manifest Islamic teaching and its values in daily basis, based on Quran and Hadith.

According to Muhaimin, from Gunawan and Ibnu Hasan, the function of Islamic education can be connected to three aspects of human being, for instance, basic potential, life purpose, and negative sides. First of all, in conjunction with human's basic potential, it is commonly acceptable that human has some potentials beyond other living creatures. Human has instinct, five senses, intelligence, and natural tendencies. Education in Islam tries improving basic potentials that human being has in order to solve life problems (in terms of science, technology, and culture), as well as increasing piety to the Almighty. Secondly, human has two main obligations, namely creating a peaceful and prosper world and managing all creatures that the Almighty created. At this point, Islamic education aims to guide and direct human beings to fulfil their obligations.

In regard to the third aspect, every human being has his/her negative sides that are pretty much complex, as explained in some Quran verses, for instance, as an unjust and ill-advised creature (AlAhzab: 72), as a weak creature (Al-Kahfi: 39), as a creature that often refutes and opposes God's teachings or commands (Al-Kahfi: 54), as a demanding creature and one who takes shortcuts to fulfil his/her wishes (Al-Isra: 11), a forgetful and wicked creature as mentioned a Hadith narrated by At-Tarmizi and Ibnu Majah, a creature who often denies God's favor and ungrateful (Al-Isra: 89), and a creature that is easily agitated, complainer, and stingy (Al-Maarij: 19-21 and Al-Isra: 100). Therefore, Islamic education aims to remind human beings for all their shortcomings and to help them to be able to control and diminish the negatives sides in themselves.

9 M. Ridlwan Nasir, Mencari Tipologi Format Pendidikan Ideal: Pondok Pesantren di Tengah Arus Perubahan (Yogyakarta, 2010), p. 56. 
In relation with the aim of Islamic education, Maragustam asserts that it is meant to create bliss in the world and the afterlife, to nurture good moral conduct, to improve kinesthetic, cognitive, spiritual, and emotional domains. Thus, human being will possess knowledge and skills, purity (tazkiyah al-nafus), etc. Additionally, Islamic education also aims to help human beings to function as attendants to foster righteous actions toward God's blessings. ${ }^{10}$

\section{The Construct of Pluralist-Multicultural Islamic Education}

Since its independence in 17 August 1945, Indonesia is a nation state which is built on multi-dimensional society. Ethnics and cultures in this country also evolve throughout the history. Pluralism in the society can be integrated into nationalism which binds national solidarity. However, diversity is God's privilege. It can be seen as blessings since varieties in tribes, race, ethnic, culture, languages, and religion are valuable assets for the country. There should be respectable perspective and attitude to maintain the assets; thus, they can globally progress and mature in plural and multicultural settings.

Recently, there are still indications on the nation's disintegration shown in radical and anarchic acts in various regions. One of the causes is society's lack of understanding on the nations' history on pluralism as reflected in Bhinneka Tunggal Ika. ${ }^{11}$ With the facts that there are still many radical and anarchic acts happen recently, there should be an effort to create harmony in the plural society. Education is a fundamental factor in improving life quality, as well as a key factor on social and economic development. There should be a form of education to link the gaps among the multi-dimension Indonesian citizens to create integration and unity.

10 Maragustam, Filsafat Pendidikan Islam: Menuju Pembentukan Karakter Menghadapi Arus Global (Yogyakarta: Kurnia Kalam Semesta, 2010), p. 202.

11 Tanto Sukardi and Subandowo, "Mencari Format Baru Pendidikan Berbasis Multikultural Di Indonesia,” Sosio DIdaktika Vol. 1, no. 1 (May 2014): p. 104. 
Pluralist-multicultural Islamic education is a type of education that suits the condition of Indonesia and its diversity. Usman Abu Bakar and Jajat Darojat mention that pluralist-multicultural Islamic education is an education system that goes hand-in-hand with Islamic values and uses pluralist-multicultural approach. ${ }^{12}$ Islamic education is a systemic effort to build understanding, comprehension, and conscience among students on pluralist-multicultural reality. ${ }^{13}$

According to Ngainun Na'im and Achmad Sauqi, pluralistmulticultural education is an attitude towards accepting pluralism on human cultural expression in understanding the message of religion. This educational construction is oriented to pluralism awareness on religion and multiculturalism. Moreover, the construction of pluralistmulticultural Islamic education can be seen as a part of comprehensive and systematic efforts to prevent religion and ethic-based conflict, religious radicalism, and the nation's disintegration. ${ }^{14}$

In a uniformed education, there are chances of creativity dead-end and intolerant attitude and perspective. Therefore, the implementation of pluralist-multicultural education is highly required. This education will create students with wider standpoints and having tolerance and respect to diversity. Pluralist-multicultural Islamic education generates human beings with a spirit of respecting others dignity. ${ }^{15}$

\section{Designing Pluralist and Multicultural-Based Curriculum}

In the Law No. 20/2003 on National Education System, it is stated that curriculum is a set of plan and regulation on the purpose, content, material, and method used as a guideline on conducting learning activities to achieve particular educational goals.

12 Usman Abu Bakar and Jajat Darojat, Pendidikan Islam Pluralis Multikultural (Yogyakarta: Media, 2013), p. 8.

13 Bakar and Darojat, p. 71.

14 Ngainun Naim and Achmad Sauqi, Pendidikan Multikultural: Konsep dan Aplikasi (Yogyakarta: Ar-Ruzz Media, 2011), p. 52.

15 Naim and Sauqi, p. 9. 
According to Muhaimin, curriculum is one of essential components in educational activities and the implementation of particular idealism and purpose that a society has. Curriculum determines directions, alternatives, functions, and results of education that will be achieved from the educational activities. Thus, curriculum becomes a center of discussion in various scientific forums; there is actually a saying "change in materials equals to change in curriculum". 16

Curriculum has a central role in a whole educational process. It conducts all educational activities to achieve predetermined goals. Also, curriculum is an educational plan that gives guideline on type, scope, sequence of contents, and educational process. Curriculum is not only a written plan for teaching, but also a functional parameter that operates in class, to give instructions on managing environment and activities in the class.

Nana Syaodih Sukmadinata asserts that curriculum has to fulfil four components, namely purpose, content or material, process or delivery, and media. These four components are intertwined one another. She adds that curriculum should have suitability or relevance which covers two points. First is relevant to the demand, need, condition, and situation of a certain society. Second is relevant in between components in the curriculum itself, which shows conformity between content and purpose, process with content and purposes. It also shows conformity among evaluation, process, content, and purpose of the curriculum. ${ }^{17}$

The characteristics of Islamic education curriculum are in five points. First is it points out religious purposes and attitudes. Second is its diverse yet comprehensive points on consideration and content. Third is relative promptness on the curriculum's content which discusses

16 Muhaimin, Rekonstruksi Pendidikan Islam: Dari Paradigma Pengembangan, Manajemen Kelembagaan, Kurikulum Hingga Strategi Pembelajaran (Yogyakarta: Raja Grafindo Persada, 2009), p. 2.

17 Indriyani Ma’rifah, "Rekonstruksi Pendidikan Agama Islam: Sebuah Upaya Membangun Kesadaran Multikultural Untuk Mereduksi Terorisme Dan Radikalisme Islam," in Conference Proceedings: Annual International Conference on Islamic Studies (AICIS) XII (Annual International Conference on Islamic Studies (AICIS) XII, Surabaya - Indonesia, 2012), p. 24. 


\section{2}

\section{Burhan Nudin}

science, art, and necessity, as well as diverse teaching experience and activities. Fourth is tendency to fine arts, physical education, military training, engineering, vocational and language skills. Fifth is relation between curriculum and learner's readiness and interest, capacity, necessity, and individual requirement. ${ }^{18}$

The formulation of Islamic education curriculum which focuses on tolerance needs to be promptly conducted. It is due to the increasing number of religion-based violence. Islamic education curriculum which focuses on tolerance can be a guideline for teachers in conveying materials on Islamic teachings that put respect on diversity.

Pluralist-multicultural Islamic education, which is taught either in civic education or Islamic religious education, has to be delivered comprehensively. It should be started from designing and planning the curriculum with inclusion, enrichment and or reinforcement from the existing competences. Designing learning process can improve students' attitude to respect others' right in spite of race, religion, language, and culture. Moreover, they will no longer see one another as majority or minority. The achievement of pluralist-multicultural Islamic education should be able to be measured through relevant evaluation, either from test or non-test instrument or continuous and balanced observation using students' portfolios.

The expected competence standard is being a citizen who is able to live side-by-side in harmony with other citizens. He/she respects different races, religions, languages, and cultures, as well as appreciates others' right. This citizen also gives equal chance to all groups in his/ her society to develop their cultures and initiates cooperation to create a worldwide respected nation. There are some basic competences specified from the abovementioned competence standard.

1. To be a citizen who can accept differences in ethnics, religions, languages, and cultures in the society.

18 Ahmad Busyairi and Azharuddin Sahil, Tantangan Pendidikan Islam (Yogyakarta: Lembaga Pers Mahasiswa, Universitas Islam Indonesia(LPM-UII), 1987), p. 17. 
2. To be a citizen who can initiate multi-ethnic, multicultural, and multi-religion cooperation in improving the nation's economic and defense.

3. To be a citizen who can appreciate other citizen's right in spite of differences in ethnics, religions, languages, and cultures in the area of social, education, economy, politics, and language and culture development.

4. To be a citizen who can create equal chance to other citizens to get their ideas and inspirations represented in legislative and executive boards.

5. To be a citizen who can develop a nondiscriminatory attitude as well as sense of justice toward fellow citizens in spite of differences in ethnics, religions, languages, and cultures.

These five basic competences, which become the basic principles in pluralist-multicultural Islamic education, do not go in contrary with both legal and ethics in Islamic teachings or other religious teachings. Furthermore, these competences have been adopted as national values that need to become basic considerations in developing approach or policy in the society. ${ }^{19}$

19 Dede Rosyada, "Pendidikan Multikultural Di Indonesia: Sebuah Pandangan Konsepsional," Sosio DIdaktika 1, no. 1 (May 2014): p. 10."abstract”:”This article was written to provide an overview of the conceptual view of multicultural education inIndonesia. In order to obtain data on the concept of multicultural authors conducted a study of literatures. As we know that Indonesia is a country with ethnic diversity but it aspires to the same goal, that is to the wealthy and prosperous society. Therefore, it becomes important to develop multicultural education, which is an educational process that gives equal opportunities to all children including minorities regardless of their differences in ethnicity, culture and religion, to strengthen the unity and integrity, national identity and the nation's standing in the international world. In this case, the school must design the learning process, preparing curriculum and evaluation design, as well as prepare teachers who have the multicultural perception, attitude and behavior, so that they becomes part of those make a signifi cant contribution to the development of multicultural attitude of the students."'ttitle-short":"Pendidikan Multikultural di Indone-

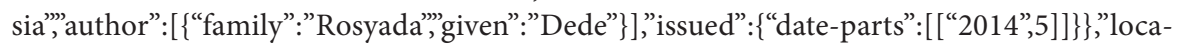
tor":"10"\}],"schema":"https://github.com/citation-style-language/schema/raw/master/csl-citation.json"\} 


\section{E. Presenting Pluralist-Multiculturalist Teachers}

Designing pluralist-multicultural curriculum is a basic need in developing multicultural principles. However, the curriculum will useless without teachers delivering it. To present pluralistmulticulturalist teachers is inseparable from the attempt of reducing radical and anarchic acts in Indonesia. Therefore, there are some teacher's qualifications in developing pluralist-multicultural learning, such as:

1. the teacher has to possess good pedagogical skills, comprehension, experience, and cultural values. Accordingly, he/she can understand his/her students who have different background and accept the difference in establishing learning activities in class.

2. the teacher has to be able to conduct self-reflection; whether or not he/she already gives fair attitude and treatment to students with different background and gender.

3. the teacher has to be able to apply dynamic pluralistmulticultural Islamic education. Thus, he/she is expected to enrich his/her understanding not only on pedagogical subjects, but also on conceptual knowledge, like, culture, immigration, race, sex, cultural assimilation, ethic gap, stereotype, prejudice, and racism.

4. the teacher has to possess adequate knowledge about histories, characteristics, and internal differences in each ethnic or racial group.

5. the teacher has to be able to conduct comparative analysis and to make a conclusion in managing social diversity. Hence, it becomes strong potential to build civilized and noble nation. ${ }^{20}$

\section{F. Pluralist-Multicultural-based School Subjects}

Pluralist-multicultural Islamic education should be able to give

20 Rosyada, p. 12. 
comprehension on the existence of plural society which requires bonds of civilization. The education also tries to link the gap between culture, ethnic, race, and religion in Indonesia. In order to build diversity in school, there are some school subjects that can be established in multicultural environment, such as:

First is Quranic materials. It can be conducted by giving selected verses, in addition to ones which discussed faith, to give comprehension and establishment on proper attitude when students have to handle interaction with people from different religions. Therefore, tolerance and inclusive habits can be rooted as early as possible. The first Quranic material discusses pluralism and acts of kindness stated in Al-Baqarah [2]: 48. The second material discusses recognition of nonviolent concurrence in inter-religious relations stated in Al-Mumtahanah [60]: 8-9. The third material discusses justice and equality stated in An-Nisa' [4]: 35.

Second is fiqh (Islamic jurisprudence) material. It can be extended by discussion on fiqh siyasah (state administration). In fiqh siyasah, there are discussions on national conceptions shown in the examples in the era of Prophet Muhammad, his companions, and caliphates after them. In the era of Prophet Muhammad, for instance, it is shown how to manage and lead the multi-ethic, multicultural, and multi-religion societies of Medina which was similar to the current condition of Indonesia. ${ }^{21}$

Next is moral lessons which focus on proper attitude to the Almighty, Prophet Muhammad, oneself, other human beings, and his/her surroundings, as well as give meaning to nationalism values. In addition, the life of a nation highly depends on moral. When a nation turns down its moral values, it will no longer exist. In the Quran, there is a story about the extinction of Luth people due to their moral decline. To make this multicultural religious education can be effectively implemented, the role of Islamic education teachers is key.

21 Muqoyyidin, “Membangun Kesadaran Inklusif-Multikultural," p. 144. 


\section{Burhan Nudin}

Beside developing diverse teaching methods, the teachers should be able to be example to their students.

The following is material on Islamic leadership studies. It is mainly based on historical facts and realities practiced by Prophet Muhammad when he built Medina. Here, there are facts on recognition and appreciation on the value of pluralism and tolerance. Therefore, emphasis on similarities among religions, changes in religious education orientation which previously fiqh-oriented to universalrabbaniyah oriented, more attention and attempt to humanity, and attempts to avoid egocentricity in faith can generate characteristics of pluralist-multicultural Islamic education. ${ }^{22}$

\section{G. A Comprehensive Evaluation System}

Evaluation is an assessment tool for education quality. It gives benefits not only for teacher, but also for student. For teacher, education evaluation will give them assurance on the efforts made. Thus, he/ she will have physical and psychological guidelines to determine his/her subsequent mandatory steps. For student, evaluation will didactically give boost or motivation to improve and maintain his/her achievements. ${ }^{23}$

Evaluation has an essential position since it is an integral part of learning process. Therefore, it will be a medium to determine the level of accomplishment of all learning activities, become a quantifiable source of information, and identify the obstacles faced in the process of achieving goals that have been formulated. Evaluation is not only essential for giving a meaning to student's learning process, but also proving feedback to the whole process. Hence, the essence of evaluation is providing information to stakeholders who manage learning process in making decision. 
Cognitive, psychomotor and affective aspects have to be assessed with relevant tools to generate students with intellectual, emotional, and spiritual intelligence. Therefore, evaluation will not only be seen from cognitive standpoint, but also create students with authentic attitude and action. It will also generate students who live and implement values achieved from learning process in their daily lives.

Evaluation to students can be given in form of numerical and working values. Numerical value is a score derived from students' exam results. On the other hand, working value is a score derived from students' personality, such as, ethic, perseverance, discipline, skillfulness, etc. Questions given in examination cannot only be in form of multiple choices, but should also be in form of essay, spoken test, etc. It aims to avoid students memorizing the whole lessons. It will help them to critically, rationally, and argumentatively analyze the given problem. The questions need to be related to recent diversity issues and guided to positive conception on different religions. ${ }^{24}$ The evaluation is determined by assessment made on students' attitude, namely perception, appreciation and response to different culture, religion, race and language. Hence, pluralist-multicultural Islamic education can create and shape the character of peace in the society. It will nurture mutual respect, tolerance, non-violence, and consistency in implementing Islamic values in their everyday life.

\section{H. Conclusion}

Horizontal conflicts begin with over-fanatics, exclusivism, radicalism, and anarchy. These actions are the results of inability to pay respect on differences existed in society. Furthermore, the inability will lead to disintegration. Every culture has its own wisdoms. These wisdoms cannot simply be valued from other culture.

Pluralist-multicultural Islamic education has to be able to provide understanding on diversity existed in the society. It requires civilized

24 Muqoyyidin, “Membangun Kesadaran Inklusif-Multikultural," p. 255. 


\section{Burhan Nudin}

bonds sourced from interaction among cultures in a particular society. Pluralist-multicultural Islamic education is an effort made to link the gaps emerged by diversity in culture, ethnic, race, language, and religion in Indonesia.

Designing curriculum of Islamic education with values of tolerance is an urgent step to be taken. Recently, there are a number of violent acts based on different culture, ethnic, race, language, and religion. This curriculum is an essential component which will become a guideline for teachers in exploring topics on Islamic teachings on respecting diversities. As a result, pluralist-multicultural Islamic education can create and shape the character of peace in the society. It will also nurture mutual respect, tolerance, non-violence, and consistency in implementing Islamic values in their everyday life. 


\section{REFERENCES}

Bakar, Usman Abu, and Jajat Darojat. Pendidikan Islam Pluralis Multikultural. Yogyakarta: Media, 2013.

Busyairi, Ahmad, and Azharuddin Sahil. Tantangan Pendidikan Islam. Yogyakarta: Lembaga Pers Mahasiswa, Universitas Islam Indonesia(LPM-UII), 1987.

Gunawan, and Ibnu Hasan, eds. Percikan Pemikiran Pendidikan Islam: Antologi Konfigurasi Pendidikan Masa Depan. Jakarta: Raja Grafindo Persada, 2015.

Mahmud. Pemikiran Pendidikan Islam. Bandung: Pustaka Setia, 2011.

Maragustam. Filsafat Pendidikan Islam: Menuju Pembentukan Karakter Menghadapi Arus Global. Yogyakarta: Kurnia Kalam Semesta, 2010 .

Ma’rifah, Indriyani. "Rekonstruksi Pendidikan Agama Islam: Sebuah Upaya Membangun Kesadaran Multikultural Untuk Mereduksi Terorisme Dan Radikalisme Islam.” In Conference Proceedings: Annual International Conference on Islamic Studies (AICIS) XII. Surabaya - Indonesia, 2012.

Muhaimin. Rekonstruksi Pendidikan Islam: Dari Paradigma Pengembangan, Manajemen Kelembagaan, Kurikulum Hingga Strategi Pembelajaran. Yogyakarta: Raja Grafindo Persada, 2009.

Muqoyyidin, Andik Wahyun. "Membangun Kesadaran InklusifMultikultural Untuk Deradikalisasi Pendidikan Islam.” Jurnal Pendidikan Islam Vol. 2, no. 1 (June 2013): 131-51.

Naim, Ngainun, and Achmad Sauqi. Pendidikan Multikultural: Konsep dan Aplikasi. Yogyakarta: Ar-Ruzz Media, 2011.

Nasir, M. Ridlwan. Mencari Tipologi Format Pendidikan Ideal: Pondok Pesantren di Tengah Arus Perubahan. Yogyakarta: Pustaka Pelajar, 2010. 


\section{Burhan Nudin}

Praja, Juhaya S. Filsafat Hukum Islam. Bandung: Universitas LPPM, Universitas Islam Bandung, 2002.

Rosyada, Dede. "Pendidikan Multikultural Di Indonesia: Sebuah Pandangan Konsepsional." Sosio DIdaktika Vol. 1, no. 1 (May 2014): 1-12.

Sanjaya, Wina. Strategi Pembelajaran Berorientasi Standar Proses Pendidikan. Jakarta: Kencana, 2011.

Sukardi, Tanto, and Subandowo. "Mencari Format Baru Pendidikan Berbasis Multikultural Di Indonesia." Sosio DIdaktika Vol. 1, no. 1 (May 2014): 99-110. 